\title{
Model Search Engine Optimization bagi Usaha Mikro Kecil dan Menengah (UMKM) di Bandung Barat
}

\author{
ASEP ID HADIANA $1^{1}$ \\ ${ }^{1}$ Jurusan Informatika, FSI Unjani \\ Email: ahadiana@gmail.com
}

\begin{abstract}
ABSTRAK
Internet telah memegang peranan yang cukup besar dalam mengembangkan sebuah usaha, karena memiliki jangkauan yang tidak terbatas. Namun tidak semua pelaku usaha mampu memanfaatkan Internet untuk memperluas jangkauan usaha mereka. Search Engine Optimization (SEO) adalah sebuah cara untuk meningkatkan visibilitas sebuah usaha di mesin pencari. Untuk usaha kecil dan menengah yang ingin bersaing di ceruk yang sama dengan perusahaan yang lebih besar dengan sumber daya yang lebih besar yang mereka miliki, memiliki strategi SEO yang kuat sangat penting. Terlepas dari industri apa yang dijalani, akan selalu memiliki setidaknya satu pesaing yang telah ada lebih lama dan telah mengalokasikan lebih banyak anggaran dan sumber daya untuk membangun visibilitas mereka di web dan di mesin pencari. Pemilik bisnis online akan tahu bahwa bagian dari pertempuran untuk memastikan bisnis sukses adalah dalam memastikan website mereka memiliki peringkat yang baik di mesin pencari. Dalam perekonomian Indonesia, Usaha Mikro, Kecil, dan Menengah (UMKM) adalah kelompok usaha yang memiliki jumlah paling besar dan terbukti tahan terhadap berbagai macam goncangan krisis ekonomi. Namun sayangnya, UMKM belum mampu memanfaatkan potensi Internet dalam memperluas pemasaran mereka, termasuk UMKM di Bandung Barat. Untuk itu diperlukan membuat model SEO bagi para UMKM di Bandung Barat.
\end{abstract}

Kata kunci: UMKM, SEO, Bandung Barat. 


\section{PENDAHULUAN}

Internet telah memegang peranan yang cukup besar dalam mengembangkan sebuah usaha, karena memiliki jangkauan yang tidak terbatas. Namun tidak semua pelaku usaha mampu memanfaatkan Internet untuk memperluas jangkauan usaha mereka. Search Engine Optimization (SEO) adalah sebuah cara untuk meningkatkan visibilitas sebuah usaha di mesin pencari. Untuk usaha kecil dan menengah yang ingin bersaing di ceruk yang sama dengan perusahaan yang lebih besar dengan sumber daya yang lebih besar yang mereka miliki, memiliki strategi SEO yang kuat sangat penting. Terlepas dari industri apa yang dijalani, akan selalu memiliki setidaknya satu pesaing yang telah ada lebih lama dan telah mengalokasikan lebih banyak anggaran dan sumber daya untuk membangun visibilitas mereka di web dan di mesin pencari.

Dalam perekonomian Indonesia, Usaha Mikro, Kecil, dan Menengah (UMKM) adalah kelompok usaha yang memiliki jumlah paling besar dan terbukti tahan terhadap berbagai macam goncangan krisis ekonomi. Kriteria usaha yang termasuk dalam UMKM telah diatur dalam payung hukum berdasarkan Undang-Undang Nomor 20 Tahun 2008 tentang Usaha Mikro, Kecil dan Menengah (UMKM) ada beberapa kriteria yang dipergunakan untuk mendefinisikan pengertian dan kriteria UMKM.

Mesin Pencari merupakan pintu masuk utama untuk menuju sebuah situs. User pada umumnya menggunakan mesin pencari untuk memulai pencarian sesuatu di Internet. Berada pada posisi teratas atau pada halaman pertama mesin pencarian, tentunya akan memberikan keuntungan bagi sebuah situs, karena akan memiliki pengunjung yang banyak. SEO merupakan salah satu teknik untuk membuat sebuah situs berada pada halaman awal mesin pencari.

Pemilik bisnis online akan menyadari bahwa bagian dari persaingan untuk memastikan bisnis sukses adalah dalam memastikan website mereka memiliki peringkat yang baik di mesin pencari. UMKM belum mampu memanfaatkan potensi Internet dalam memperluas pemasaran mereka, termasuk UMKM di Bandung Barat. Untuk itu diperlukan membuat model SEO bagi para UMKM di Bandung Barat.

Geografis Kabupaten Bandung Barat terletak pada $06^{\circ} 41^{\prime} 07^{\circ} 19^{\prime}$ Lintang Selatan dan $107^{\circ} 22^{\prime}-108^{\circ}$ 05' Bujur Timur. Keseluruhan wilayah Kabupaten Bandung Barat memiliki luas wilayah $1.305,77 \mathrm{Km} 2$ atau $130.577,40 \mathrm{Ha}$ yang terbagi menjadi 16 wilayah administrasi Kecamatan yaitu Lembang, Parongpong, Cisarua, Cikalongwetan, Cipeundeuy, Ngamprah, Cipatat, Padalarang, Batujajar, Cihampelas, Cililin, Cipongkor, Rongga, Sindangkerta, Gununghalu dan Saguling. Secara Geografis Kabupaten Bandung Barat Terletak di antara 60,3 73' sampai dengan 70,1 31' Lintang Selatan dan 1070,1 10' sampai dengan 1070,4 40' Bujur Timur. (Ginanjar, 2016).

Hasil studi lapangan pada UMKM di Kabupaten Bandung Barat menunjukkan bahwa salah satu aspek yang terkait dengan masalah pemasaran yang umum dihadapi oleh UMKM adalah tekanan -tekanan persaingan, baik di pasar domestik dari produk produk serupa buatan luar negeri dan impor, maupun di pasar ekspor. (Ginanjar, 2016).

Pada penelitian lain yang telah dilakukan pada sebuah UMKM, Hasil dari search engine optimization yang dilakukan pemilik terhadap toko online-nya membuahkan hasil berupa meningkatkan jumlah penjualan dan pesanan order jaket hingga ke pasar Internasional. Hal ini dikarenkan website toko online "www.pesanjaketonline.com" terindex di mesin pencari Google di halaman pertama.(Fauzan, 2017) 


\section{LANDASAN TEORI}

\subsection{Pemasaran}

Aktifitas sebuah usaha tidak akan terlepas dari proses Pemasaran. Pemasaran adalah suatu aktifitas dalam perekonomian yang dilakukan oleh suatu organisasi untuk menciptakan, menghubungkan, menawarkan dan menentukan nilai ekonomi suatu barang atau jasa kepada pelanggan. Penentuan nilai harga suatu barang dan jasa dipengaruhi oleh 3 faktor, yaitu : produksi, pemasaran dan konsumsi. (Kotler, 2000).

Ada empat ukuran pangsa pasar (Kotler, 2000), yaitu:

(1) Pangsa pasar keseluruhan yang dinyatakan sebagai persentase dan penjualan industri seluruhnya.

(2) Pangsa pasar yang dilayani perusahaan penjualannya sebagai persentase dan total penjualan di pasar yang dilayani.

(3) Pangsa pasar relatif (atas tiga pesaing utama); ini mencakup penjualan perusahaan sebagai persentase dan gabungan penjualan tiga pesaing terbesar. Misalnya jika perusahaan ini mempunyai 30 persen dan pasar, dan kedua pesaing terdekatnya mempunyai 20 persen dan 10 persen, maka pangsa pasar relatif perusahaan ini menjadi 50 persen $(30 / 60)$

(4) Pangsa pasar relatif (atas pesaing yang unggul) berupa persentase terhadap penjualan pesaingnya yang paling atas.

\subsection{Search Engine Optimization (SEO)}

SEO adalah serangkaian proses sistematis untuk meningkatkan volume atau kualitas kunjungan melalui mesin pencari menuju situs tertentu dengan memanfaatkan mekanisme kerja atau algoritma mesin pencari. Secara sederhana tujuan SEO adalah menempatkan situs pada posisi teratas atau setidaknya pada halaman pertama hasil pencarian berdasarkan kata kunci yang ditargetkan. (Toharudin, 2012)

SEO merupakan sebuah teknik yang digunakan untuk memaksimalkan suatu website agar lebih dikenal atau lebih mudah dibaca oleh mesin pencari sehingga dapat muncul pada halaman awal mesin pencari sehingga menyebabkan akan memiliki pengunjung yang Banyak. Terdapat 2 macam teknik SEO yaitu SEO On Page dan SEO Off Page (Spais, 2010). SEO On Page yaitu teknik melakukan optimasi Internal website itu sendiri dengan cara memodifikasi beberapa parameter tertentu dari suatu bagian sebuah website misalkan menentukan title, tag, content yang relevan dengan title dan lain-lain. Sedangkan SEO Off Page merupakan teknik optimasi yang dilakukan dari luar bagian website dengan tetap mengacu pada algoritma search engine tertentu, misalnya dengan cara mendapatkan Backlink.

\subsection{Usaha Kecil Mikro dan Menengah (UMKM)}

Undang-Undang Nomor 20 Tahun 2008 tentang Usaha Mikro, Kecil dan Menengah (UMKM) adalah landasan hukum untuk UMKM. Berdasarkan UU Nomor 20 Tahun 2008 :

Usaha Mikro adalah usaha produktif milik orang perorangan dan/atau badan usaha perorangan yang memenuhi kriteria Usaha Mikro sebagaimana diatur dalam UndangUndang ini. 
Usaha Kecil adalah usaha ekonomi produktif yang berdiri sendiri, yang dilakukan oleh orang perorangan atau badan usaha yang bukan merupakan anak perusahaan atau bukan cabang perusahaan yang dimiliki, dikuasai, atau menjadi bagian baik langsung maupun tidak langsung dari Usaha Menengah atau Usaha Besar yang memenuhi kriteria Usaha Kecil sebagaimana dimaksud dalam Undang-Undang ini.

Usaha Menengah adalah usaha ekonomi produktif yang berdiri sendiri, yang dilakukan oleh orang perorangan atau badan usaha yang bukan merupakan anak perusahaan atau cabang perusahaan yang dimiliki, dikuasai, atau menjadi bagian baik langsung maupun tidak langsung dengan Usaha Kecil atau Usaha Besar dengan jumlah kekayaan bersih atau hasil penjualan tahunan sebagaimana diatur dalam Undang- Undang ini.

Usaha Besar adalah usaha ekonomi produktif yang dilakukan oleh badan usaha dengan jumlah kekayaan bersih atau hasil penjualan tahunan lebih besar dari Usaha Menengah, yang meliputi usaha nasional milik negara atau swasta, usaha patungan, dan usaha asing yang melakukan kegiatan ekonomi di Indonesia.

Masih menurut UU No. 20 Tahun 2008 :

Kriteria Usaha Mikro adalah sebagai berikut:

a. memiliki kekayaan bersih paling banyak Rp50.000.000,00 (lima puluh juta rupiah) tidak termasuk tanah dan bangunan tempat usaha; atau

b. memiliki hasil penjualan tahunan paling banyak Rp300.000.000,00 (tiga ratus juta rupiah).

Kriteria Usaha Kecil adalah sebagai berikut:

a. memiliki kekayaan bersih lebih dari Rp50.000.000,00 (lima puluh juta rupiah) sampai dengan paling banyak Rp500.000.000,00 (lima ratus juta rupiah) tidak termasuk tanah dan bangunan tempat usaha; atau

b. memiliki hasil penjualan tahunan lebih dari Rp300.000.000,00 (tiga ratus juta rupiah) sampai dengan paling banyak Rp2.500.000.000,00 (dua milyar lima ratus juta rupiah).

Kriteria Usaha Menengah adalah sebagai berikut:

a. memiliki kekayaan bersih lebih dari Rp500.000.000,00 (lima ratus juta rupiah) sampai dengan paling banyak Rp10.000.000.000,00 (sepuluh milyar rupiah) tidak termasuk tanah dan bangunan tempat usaha; atau

b. memiliki hasil penjualan tahunan lebih dari Rp2.500.000.000,00 (dua milyar lima ratus juta rupiah) sampai dengan paling banyak Rp50.000.000.000,00 (lima puluh milyar rupiah).

\section{PEMBAHASAN}

\subsection{Riset Kata Kunci (Keyword Research)}

Riset kata kunci adalah salah satu aktivitas yang paling penting dalam SEO. Peringkat untuk kata kunci yang tepat dapat membuat sebuah website memiliki banyak pengunjung. Dengan 
memilih kata kunci yang tepat sesuai dengan area usaha, website UMKM memiliki potensi untuk dikunjungi oleh banyak pelanggan. Kunjungan yang banyak terhadap sebuah website UMKM, akan meningkatkan potensi penjualan. Dalam penelitian ini, diambil sampel sebuah UMKM yang memiliki usaha di bidang Makanan dan Minuman, yaitu Bandrek. Akan dicari kata kunci turunan yang tepat untuk kata kunci Utama Bandrek.

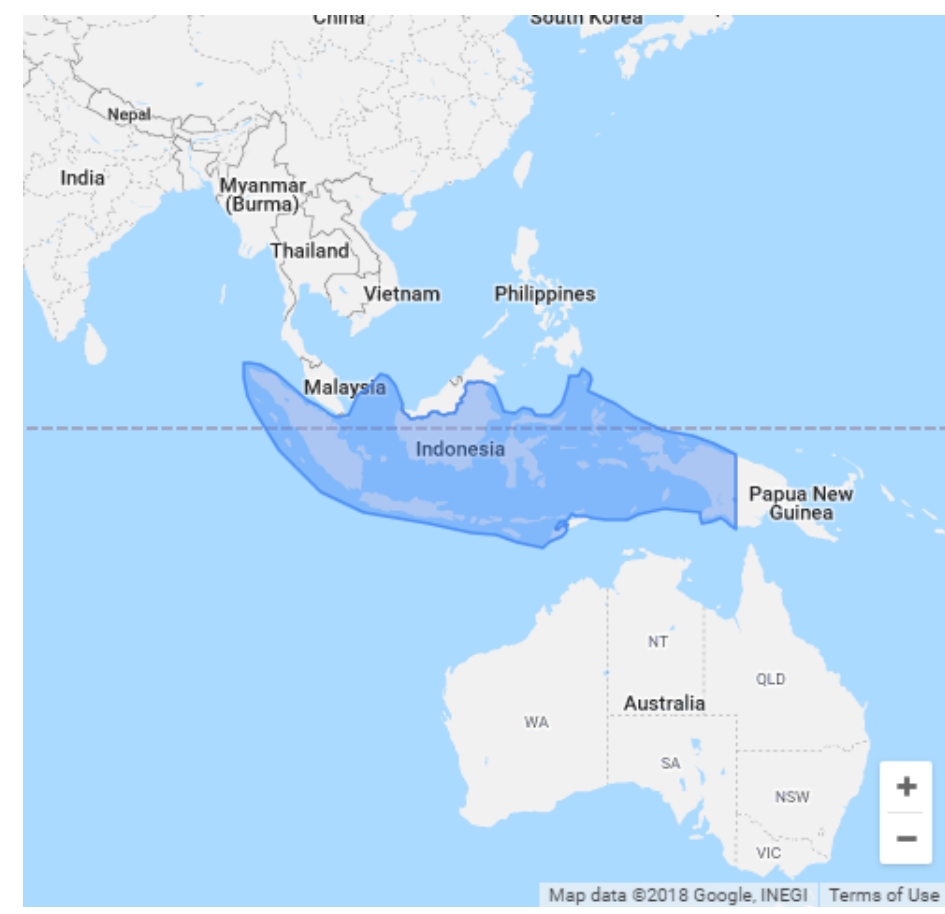

Gambar 1. Target kata Kunci wilayah Indonesia

Dengan menggunakan tools yang ada di Internet, seperti Ahrefs, yang bisa diakses melalui halaman website http://www.ahrefs.com, pelaku UMKM dapat melakukan riset kata kunci secara mandiri. Dengan memasukkan kata kunci Bandrek, hasilnya dapat dilihat pada gambar 2.

\section{Overview: bandrek Data updated 9 May '18 18 C Update}

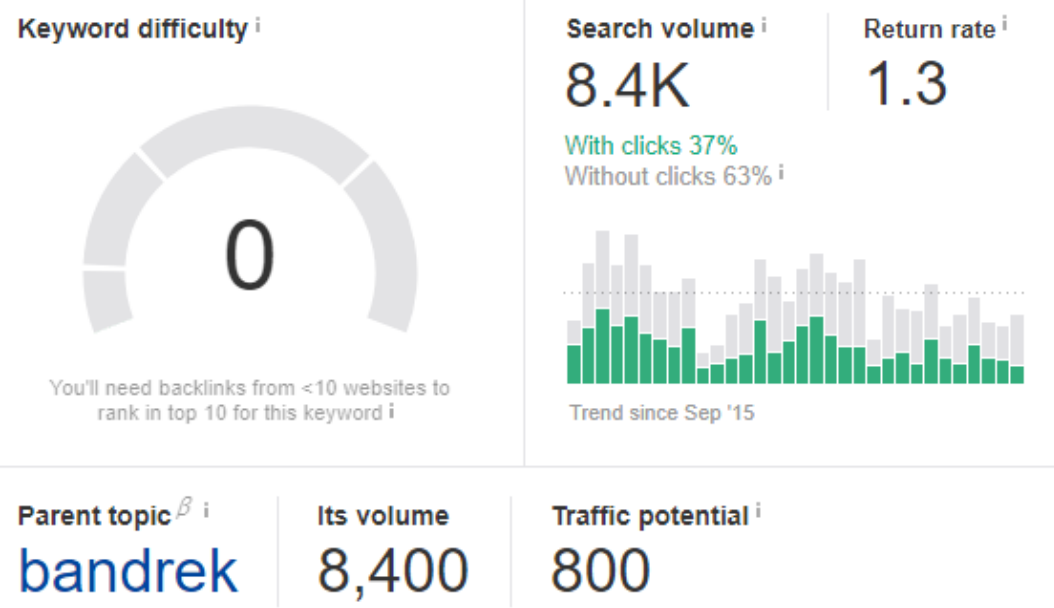

Gambar 2. Hasil pencarian untuk kata kunci Bandrek 
Dari gambar 2, dapat dilihat bahwa kata kunci Bandrek memiliki jumlah pencarian perbulan sekitar 8.400 pencarian. Kemudian memiliki keyword difficulty (tingkat persaingan) 0, yang berarti mudah untuk di targetkan sehingga apabila website UMKM menerapkan konsep SEO yang sederhanapun, halaman website UMKM tersebut akan muncul pada halaman pertama mesin pencari, dalam hal ini Google.

Namun untuk melengkapi isi sebuah website, maka dibutuhkan beberapa kata kunci turunan untuk kata kunci Bandrek tersebut. Masih menggunakan tools yang sama yaitu Ahrefs, bisa didapatkan beberapa kata kunci turunan dari Bandrek berikut dengan keyword difficultynya seperti yang terlihat pada gambar 3 .

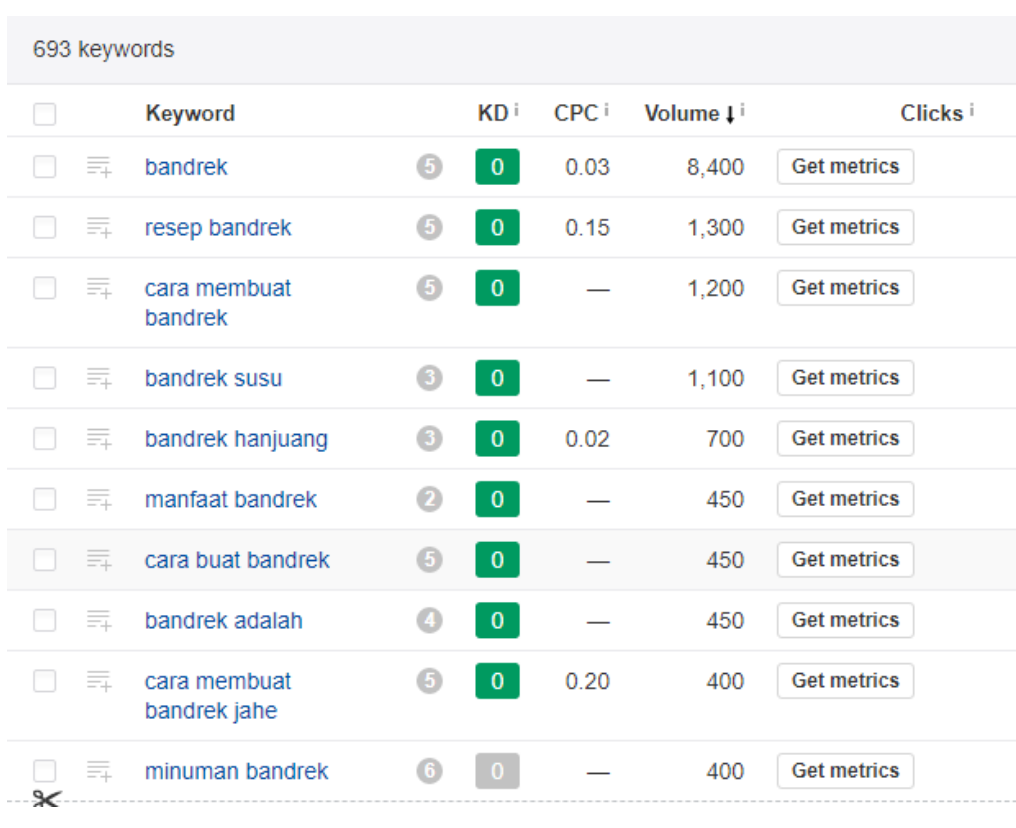

\section{Gambar 3. Kata Kunci Turunan untuk Bandrek}

Dari gambar 3, diperoleh beberapa kata kunci turunan untuk kata kunci utama Bandrek, seperti resep bandrek, bandrek susu, bandrek hanjuang dan beberapa kaca kunci lainnya.

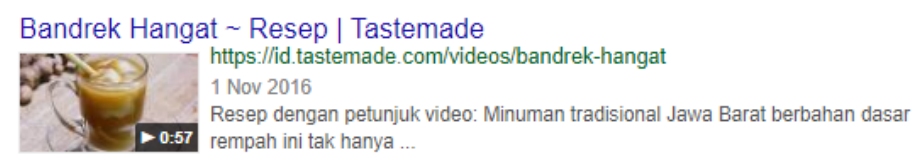

\begin{tabular}{|c|c|}
\hline bandrek medan & $10 / \mathrm{mo}-50.00-0 \triangleq$ \\
\hline resep bandrek asli & $10 / \mathrm{mo}-50.00-0$ 党 \\
\hline bandrek susu adalah & $0 / \mathrm{mo}-\$ 0.00-0$ 党 $\mathrm{E}$ \\
\hline cara membuat bandrek spesial & $10 / \mathrm{mo}-\$ 0.00-0 \star$ \\
\hline bandrek bandung & $10 / \mathrm{mo}-50.00-0 \Rightarrow$ \\
\hline bandrek aceh & $10 / \mathrm{mo}-50.00-0 \triangleq$ \\
\hline bandrek susu disebut juga & $0 / \mathrm{mo}-\$ 0.00-0 \pm$ \\
\hline na lain bandrek susu & $0 / \mathrm{mo}-\$ 0.00-0$ 吉 $\mathrm{g}$ \\
\hline
\end{tabular}


Setelah mendapatkan beberapa kata kunci turunan untuk kata kunci Bandrek, seperti terlihat pada gambar 3 dan gambar 4, selanjutnya tinggal membuat artikel yang berhubungan dengan kata kunci turunan yang didapatkan.

\subsection{SEO On Page}

Salah satu teknik SEO yang mudah diterapka adalah dengan menggunakan SEO On Page, karena bisa dikerjakan pada bagian internal website kita.

a. Title Tag

Title tag merupakan salah satu komponen yang sangat penting dalam SEO On Page.

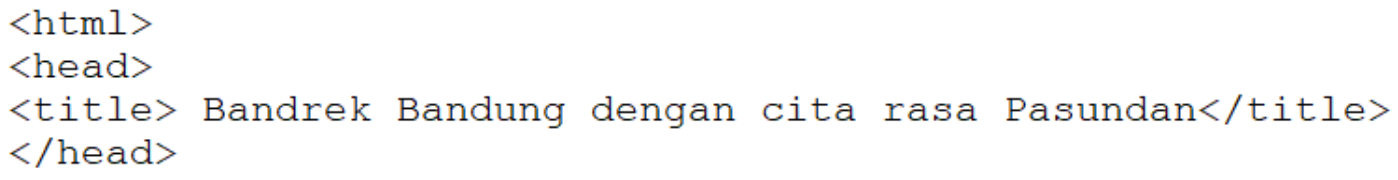

\section{Gambar 5. Optimasi Title Tag}

b. Meta Description

$<$ html $>$

$<$ head $>$

$<$ title $>$ Bandrek Bandung dengan cita rasa Pasundan $</$ title $>$

$<$ head $>$

$<$ meta name="description" content="Anda mencai Bandrek Enak? Situs ini menyediakan berbagai artikel dan produk mengenai Bandrek Bandung.">

$</$ head $>$

c. Tag $\mathrm{H} 1$

$<$ body $>$

\section{$<$ h1 $>$ Mengenal Bandrek Bandung $</$ h1 $>$}

d. Tag $\mathrm{H} 2$

e. Sisipkan Kata Kunci pada 100 kata pertama artikel

f. Buat link keluar menuju situs terkenal

g. Buat Internal Link

h. Alt Text pada gambar

Kehadiran sebuah gambar dalam artikel akan membuat user lebih lama berada di situs kita. Optimasi gambar dilakukan dengan menambahkan tag Alt Text untuk gambar. 
<img src="Bandrek.jpg" alt="Bandrek Jahe Bandung">

\section{KESIMPULAN}

Internet telah memegang peranan yang cukup besar dalam mengembangkan sebuah usaha, karena memiliki jangkauan yang tidak terbatas. Namun tidak semua pelaku usaha mampu memanfaatkan Internet untuk memperluas jangkauan usaha mereka. Search Engine Optimization (SEO) adalah sebuah cara untuk meningkatkan visibilitas sebuah website di mesin pencari. Untuk usaha kecil dan menengah yang ingin bersaing di ceruk yang sama dengan perusahaan yang lebih besar dengan sumber daya yang lebih besar yang mereka miliki, memiliki strategi SEO yang kuat sangat penting. Terlepas dari industri apa yang dijalani, akan selalu memiliki setidaknya satu pesaing yang telah ada lebih lama dan telah mengalokasikan lebih banyak anggaran dan sumber daya untuk membangun visibilitas mereka di web dan di mesin pencari. Pemilik bisnis online akan tahu bahwa bagian dari pertempuran untuk memastikan bisnis sukses adalah dalam memastikan website mereka memiliki peringkat yang baik di mesin pencari. Dalam perekonomian Indonesia, Usaha Mikro, Kecil, dan Menengah (UMKM) adalah kelompok usaha yang memiliki jumlah paling besar dan terbukti tahan terhadap berbagai macam goncangan krisis ekonomi. Namun sayangnya, UMKM belum mampu memanfaatkan potensi Internet dalam memperluas pemasaran mereka, termasuk UMKM di Bandung Barat. Untuk itu diperlukan membuat model SEO bagi para UMKM di Bandung Barat. Penelitian ini mengusulkan sebuah model SEO untuk UMKM di Kabupaten Bandung Barat.

\section{DAFTAR RUJUKAN}

\section{Rujukan Buku:}

Kotler \& Armstrong. 2008. Prinsip-Prinsip Pemasaran. Jilid 1 dan 2 Edisi 12. Jakarta: Erlangga.

Spais, S.George, 2010, Search Engine Optimization (SEO ) as a dynamic online promotion technique: the implications of activity theory for promotion managers, Volume 6, Issue 1, Innovative Marketing, pp 7-24

Tohirudin, M. 2012. Membuat Situs Top Search, Mahir SEO untuk Pemula. Jakarta. Kanaya Press

\section{Rujukan Jurnal:}

Ginanjar, Y., \& Ratmoko, K. (2016). PERENCANAAN STRATEGIS PEMERINTAH DAERAH KABUPATEN BANDUNG DARAT DALAM PENGUATAN KAPASITAS UMKM UNTUK MENGHADAPI MASYARAKAT EKONOMI ASEAN. Jurnal Dinamika Global, Volume 01, Nomor.

Fauzan, A. , Suharyono, \& Abdillah, Y. (2017). ANALISIS PEMANFAATAN SEARCH ENGINE OPTIMIZATION DALAM MENINGKATKAN PENJUALAN PRODUK UKM DI PASAR INTERNASIONAL (Studi Kasus Pada CV. Ayung Sportindo). Jurnal Administrasi Bisnis, Vol. 50, Nomor. 6, 96 - 105. 